\title{
DNA Adduct Forming Agent
}

National Cancer Institute

\section{Source}

National Cancer Institute. DNA Adduct Forming Agent. NCI Thesaurus. Code C2163.

An agent capable of attaching to DNA with a covent bond. DNA adduct forming agents cause disruption of DNA replication and mitosis. 